\title{
ПРИЧИНИ ТРОМБОЗУ ВІДДАЛЕНОГО ПІСЛЯОПЕРАЦІЙНОГО ПЕРІОДУ РЕКОНСТРУКЦІЇ АОРТО-КЛУБОВО-СТЕГНОВОГО АРТЕРІАЛЬНОГО БАСЕЙНУ
}

Причини тромбозу віддаленого післяопераційного періоду реконструкції аорто-клубово-стегнового артеріального басейну

\section{М. О. Гусак, І. К. Венгер}

Тернопільський національний медичний університет імені І. Я. Горбачевського мОЗ України

Резюме. Основною причиною розвитку ускладнень пізнього післяопераційного періоду в пацієнтів після реконструктивних втручань на магістральних артеріях нижніх кінцівок вважається прогресування некорегованого атеросклеротичного процесу. До найчастіших ускладнень віддаленого післяопераційного періоду відносять тромбози артерій та шунтів, несправжні аневризми анастомозів, інфекційні ускладнення із поширенням процесу на судинні експлантати. Поряд з цим діагностують ряд віддалених ускладнень, що розвиваються в результаті не застосування деяких способів та методів оперативного втручання у складі реконструктивних операцій на магістральних артеріях [4].

Мета дослідження - встановити причини тромбозу у віддаленому післяопераційному періоді реконструкції аорто-клубово-стегнової зони і на їх основі запропонувати об'єм реваскуляризації аорто-клубовостегнового басейну з метою попередити їх розвиток.

Матеріали і методи. Протягом 2006-2019 рр. оперативному лікуванню піддано 522 хворих з приводу атеросклеротичної оклюзії аорто-клубово-стегнової зони. У віддаленому післяопераційному періоді діагностовано 148 (28,35\%) пізніх ускладнень, з яких у 47 (33,81 \%) спостереженнях виявлено пізній тромбоз сегмента реконструкції. Серед останніх у 37 спостереженнях - пізній тромбоз бранші аорто-клубово-біфреморального алопротеза, у 4 пацієнтів - пізній тромбоз бранші аорто-клубово-біфеморального алопротеза й одноіменної глибокої артерії стегна (ГАС), у 6 пацієнтів - тромбоз клубово-стегнового сегмента контрлатеральної нижньої кінцівки.

Результати. У 47 (33,81 \%) спостереженнях виявлено пізній тромбоз сегмента реконструкції. Представлено деякі причини розвитку тромбозу пізнього післяопераційного періоду, в яких має місце прогресування атеросклеротичного процесу, особливо в певних сегментах артеріального русла, які не були охоплені оперативним втручанням. До них віднесено 4 спостереження із пізнім тромбозом бранші аорто-клубово-бісреморального алопротеза й одноіменної ГАС та 6 спостережень із
Causes of thrombosis at the remote postoperative period of reconstruction of the aortic/iliac-femoral arterial system

M. O. Husak, I. K. Venher

I. Horbachevsky Ternopil National Medical University

e-mail: venger@tdmu.edu.ua

Summary. The main reason for the development of complications of the late postoperative period in patients after reconstructive interventions on the main arteries of the lower extremities is the progression of uncorrected atherosclerotic process. The most common complications of the remote postoperative period include thrombosis of arteries and shunts, anastomotic false aneurysms, infectious complications with the spread of the process to vascular explants. Along with this, a number of long-term complications are diagnosed, which develop as a result of not using some methods and techniques of surgical intervention as part of reconstructive operations on the main arteries.

The aim of the study - to determine the causes of thrombosis in the remote postoperative period of reconstruction of the aortic/iliac-femoral basin and, consequently, suggest the scope of revascularization of the aortic/iliac-femoral basin in order to prevent their development.

Materials and Methods. In 2006-2019, 522 patients underwent surgical treatment for atherosclerotic occlusion of the aortic/iliac-femoral system. In the remote postoperative period, 148 (28.35\%) delayed complications were diagnosed, of which late thrombosis of the reconstruction segment was detected in 47 (33.81\%) cases. Among them, in 37 cases late thrombosis of the aortic/iliac-bifemoral alloprosthesis, in 4 patients late thrombosis of the branch of aortic/iliac-bifemoral alloprosthesis and corresponding deep femoral artery, in 6 patients thrombosis of the iliac-femoral segment of the contralateral lower extremity were diagnosed.

Results. Late thrombosis of the reconstruction segment was detected in 47 (33.81\%) cases. Some reasons for the development of thrombosis of the remote postoperative period are presented, in which there is a progression of the atherosclerotic process, especially in certain segments of the arterial bed, which were not covered by surgery. These included 4 observations with late thrombosis of the branch of aortic/iliac-bifemoral alloprosthesis and the corresponding deep femoral artery and 6 observations with thrombosis of 
тромбозом клубово-стегнового сегмента контрлатеральної нижньої кінцівки. При врахуванні рівня стенотичного процесу клубово-стегнового сегмента контрлатеральної нижньої кінцівки в першому випадку та визначенні показника пікової систолічної швидкості (ПСШ) й індексу резистентності (IP) на рівні ГАС та тібіоперинеального стовбура (ТПС) у другому в умовах включення наведених артеріальних сегментів у об'єм реваскуляризуючого втручання можна попередити розвиток пізнього тромбозу наведених сегментів.

Висновки. Розвиток пізнього тромбозу на наведених артеріях магістральних сегментів можна попередити шляхом їх включення в об'єм реваскуляризуючого втручання.

Ключові слова: повторна реваскуляризація; тромбоз артерій та шунтів; хронічна артеріальна недостатність; реконструктивні операції.

\section{ВСТУП}

Не дивлячись на сучасне досягнення у судинній хірургії, частота порушень прохідності реконструйованих артерій залишається високою як у ранньому, так і у віддаленому післяопераційному періодах [5]. Ускладнення пізнього післяопераційного періоду спостерігаються у 7,934,1 \% пацієнтів [6, 7]. Основною причиною розвитку ускладнень пізнього післяопераційного періоду в пацієнтів після реконструктивних втручань на магістральних артеріях нижніх кінцівок вважається прогресування некорегованого атеросклеротичного процесу [1]. До найбільш частих ускладнень віддаленого післяопераційного періоду відносять тромбози артерій та шунтів, несправжні аневризми анастомозів, інфекційні ускладнення із поширенням процесу на судинні експлантати [2, 3]. Поряд з цим діагностується ряд віддалених ускладнень, що розвиваються в результаті не застосування деяких способів та методів оперативного втручання у складі реконструктивних операцій на магістральних артеріях [4].

Метою дослідження було встановити причини тромбозу у віддаленому післяопераційному періоді реконструкції аорто-клубово-стегнової зони і на їх основі запропонувати об'єм реваскуляризації аорто-клубово-стегнового басейну з метою попередити їх розвиток.

\section{МАТЕРІАЛИ I МЕТОДИ}

Протягом 2006-2019 рр. оперативному лікуванню піддано 522 хворих з приводу атеросклеротичної оклюзії аорто-клубово-стегнової зони. У віддаленому післяопераційному періоді діагностовано 148 (28,35 \%) пізніх ускладнень, 3 яких у 47 $(33,81 \%)$ спостереженнях виявлено пізній тромбоз сегмента реконструкції. Серед останніх у 37 спостереженнях - пізній тромбоз бранші аорто-клубово- the iliac-femoral segment of the contralateral lower extremity. Taking into account the level of stenotic process of the iliac-femoral segment of the contralateral lower extremity in the first case and determining the peak systolic velocity (PSV) and resistance index (RI) at the level of deep femoral artery and tibioperoneal trunk (TPT) in the second one, under the conditions of inclusion of the arterial segments into the scope of revascularizing intervention, the development of late thrombosis of these segments can be prevented.

Conclusions. The development of late thrombosis in the arteries of the main segments can be prevented by including them in the scope of revascularizing intervention.

Key words: repeated revascularization; thrombosis of arteries and shunts; chronic arterial insufficiency; reconstructive operations.

біфреморального алопротеза, у 4 пацієнтів - пізній тромбоз бранші аорто-клубово-біфеморального алопротеза й одноіменної глибокої артерії стегна (ГАС), у 6 пацієнтів - тромбоз клубово-стегнового сегмента контрлатеральної нижньої кінцівки.

Визначення показників згортальної та фрібринолітичної системи здійснювали наступним чином: фрібриноген (ФГ) - ваговою методикою: гравіметричним методом за Р. А. Рутбергом (1964); активність фрібриностабілізуючого фрактора (ФСФ) - за допомогою набору для визначення фрактора XIII науково-виробничої фрірми «SIMKO Ltd» (Львів); тромбопластична активність крові (ТПА) - за методом Б. А. Кудряшова і П. Д. Улітіної; час рекальцифрікації плазми (ЧРП) - за методом Бергергоф і Рока; плазмін (ПЛ), плазміноген (ПГ), сумарна фрібринолітична активність (СФА) - за методом В. А. Монастирського та співавт.(1988); час лізису еуглобінових згустків (ЧЛЕЗ) - застосувуючи набір для визначення фрібринолітичної активності плазми крові науково-виробничої фрірми «SIMKO Ltd» (Львів); дослідження агрегаційних властивостей тромбоцитів вивчали із застосуванням АДФ у концентрації 2,5 мкмоль/л із записом агрегатограм на аналізаторі АР 2110 «Солар»; час лізису еуглобінових згустків (ЧЛЕЗ) - застосуваши набір для визначення фрібринолітичної активності плазми крові науково-виробничої фрірми «SIMKO Ltd» (Львів); визначення розчинних фрібриномономерних комплексів (РФМК) проводили планшетним методом; фрактор Вілебранда (ФВ) за методикою 3. С. Баркаган (1988).

Ультразвукову доплерографрію артеріального русла нижніх кінцівок здійснювали апаратом «Ultima PA», Україна («Радмір»), використовуючи лінійний датчик із частотою 7 Мгц та конвексний датчик з частотою 3,5 Мгц.

Для діагностики оклюзійно-стенотичних уражень аорти та магістральних артерій нижніх кін- 
цівок та артерій головного мозку застосовували комп'ютерну томографрію із ангіопідсиленням на апараті «Philips Brilliance 64».

\section{РЕЗУЛЬТАТИ Й ОБГОВОРЕННЯ}

Первинну реваскуляризацію аорто-клубовостегнової зони проведено у 47 пацієнтів із ХАН ІІБ ст. у 6 спостереженнях, із ХАН IIIA ст. - в 32 осіб, із ХАН ІІІБ-IV ст. - у 9 випадках.

Згідно з рекомендаціями R. B. Rutherford et al. (1997) [8], такі ускладнення реваскуляризуючого оперативного втручання, як тромбоз сегмента реконструкції, тромбоз аорто-клубово-стегнового протеза класифрікуються як пізні тромбози за умови, що вони розвинулися в термін понад 1 місяць після реконструктивного оперативного втручання.

У віддаленому післяопераційному періоді діагностовано 47 (33,81 \%) спостережень із пізнім тромбозом сегмента реконструкції. Серед останніх у 37 спостереженнях - пізній тромбоз бранші аорто-клубово-біфеморального алопротеза, у 4 пацієнтів - пізній тромбоз бранші аорто-клубовобіфеморального алопротеза й одноіменної ГАС, у 6 пацієнтів - тромбоз клубово-стегнового сегмента контрлатеральної нижньої кінцівки.

У 37 пацієнтів пізній тромбоз бранші аорто-клубово-біфреморального алопротеза (А/КСП) діагностували на 24-72 місяці після реконструктивного втручання на аорто-клубово-стегновому басейні. Найчастіше (18 (43,9 \%)) пізній тромбоз бранші виявляли на 24-48 місяці післяопераційного періоду. Тривалість тромботичної оклюзії бранші протеза на момент госпіталізації сягала від 20 годин до 33 діб. Причиною пізнього тромбозу аорто-клубово-біфеморального алопротеза була гіперплазія неоінтими в умовах атеросклеротичного ураження зони анастомозу та запального процесу. Гіперплазія неоінтими - щільне гомогенне потовщення стінки 3 гладкою білуватою поверхнею без ознак виразкування та кальцифрікації. Атеросклеротичне ураження проявлялось у вигляді вогнищ кальцифрікації стенозованого анастомозу, нерівностями та виразкування його внутрішньої поверхні зони дистального анастомозу та прилеглих артеріальних сегментів.

Оперативне втручання у пацієнтів із пізнім тромбозом бранші A/КСП розпочинали із виділення дистального анастомозу А/КСП та стегнових артерій. Відновлення центрального кровообігу досягалося шляхом ретроградної тромбоектомії (TE) із бранші. Метод включав одночасне застосування балонних катетерів типу Fogharty для блокування входу в бранші й контролю кровотечі та петель для ендартеректомії (стриперів). Останні давали можливість відшаровували тромботичні та псевдоінтимальні нашарування від стінки алопротеза із наступною екстракцією їх решток при видаленні катетера.
Наступним етапом хірургічного втручання була резекція тромбованого ДА ( 62,2 \%) або неповне виділення ДА (37,7 \%) із виключенням його із кровообігу. Реконструкцію ДА в пацієнтів при збереженій прохідності ПСА виконано в 19 (51,4 \%) спостереженнях, при цьому було включено у кровообіг обидві стегнові артерії шляхом дисталізації їх біфуркації.

У 18 (48,7 \%) спостереженнях виникла необхідність виконати реконструкцію стегно-дистального артеріального русла. У 9 з них здійснено стегнодистальне аутовенозне, а у 7 - стегно-дистальне алошунтування. В 11 (42,7 \%) спостереженнях проксимальний анастомоз стегново-підколінного шунта фрормували за типом кінець-в-кінець бранші А/КСП. У 5 випадках проксимальний сегмент аутовенозного/алошунта вшито у зону неповно виділеного ДА А/КСП.

У двох спостереженнях виконали одномоменту реваскуляризацію бранші А/КСП та стегно-дистальної зони за методом І. І. Кобза (2004). Проводили фрормування дистального анастомозу аутовенозного шунта із прохідним термінальним сегментом поверхневої стегнової або підколінної артерії. Інший сегмент аутовени анастомозували із дистальним сегментом глибокої артерії стегна. Згодом проксимальні сегменти обох аутовенозних шунтів фрормували у спільне гирло, яке анастомозували із браншею А/КСП за типом кінець-В-кінець.

У 4 пацієнтів пізній тромбоз бранші аорто-клубово-біфеморального алопротеза і ГАС сформувався в строки 3 місяці післяопераційного періоду. Тривалість тромботичної оклюзії бранші протеза на момент госпіталізації сягала від 19-49 год. Причиною розвитку тромбозу був недостатній об'єм реконструкції магістрального русла проблемної нижньої кінцівки. У пацієнтів первинно було діагностовано атеросклеротичну оклюзію аорто-клубової зони, стеноз біфуркації ЗАС із втягненням у процес ГАС, оклюзія ПАС з поширенням на ПА. У наведених умовах було проведено лише аортоклубово-біфеморальне алошунтування, дистальний анастомоз алошунта формували після профрундопластики ГАС. При цьому не було достатньої впевненості у задовільному фрункціонуванні анастомозів ГАС із низхідною артерією коліна, підколінною артерією та гомілковими артеріями. Протягом тримісячного післяопераційного періоду функціональна здатність вищенаведених анастомозів погіршилась, що і призвело до розвитку тромбозу ГАС і бранші алопротеза.

При госпіталізації у пацієнтів із пізнім тромбозом бранші аорто-клубово-біфеморального алопротеза і ГАС після виділення дистального А/КСП та стегнових артерій здійснювали відновлення центрального кровообігу шляхом ретроградної тромбоектомії (TE) із бранші алопртеза. ТЕ включала одночасне застосування балонних катетерів типу Fogharty для 
блокування входу в браншу і контролю кровотечі та петель для ендартеректомії (стриперів). Після неповного виділення дистального анастомозу А/КСП виконували стегно-дистальне аутовенозне шунтування, де проксимальний анастомоз аутовени фрормували в зоні неповно виділеного дистального анастомозу А/КСП, а дистальний - на рівні підколінної артерії (3 спостереження) і задньої великогомілкової артерії (1 спостереження).

Для попередження розвитку пізнього тромбозу бранші А/КСП і ГАС у пацієнтів із багаторівневою оклюзією магістральних артерій нижньої кінцівки необхідно визначати стан ГАС шляхом проведення сонографічного дослідження на рівні ГАС та тібіоперинеального стовбура (ТПС). При показнику пікової систолічної швидкості (ПСШ) й індексу резистентності (IP) на рівні ГАС нижчому, відповідно, за $(43,7 \pm 6,1) \mathrm{cm} / \mathrm{c}$ і $(0,58 \pm 0,09)$ ум. од. та показнику ПСШ і IP на рівні ТПС нижчому, відповідно, за $(32,9 \pm 2,8)$ cм/с і $(0,50 \pm 0,08)$ ум. од. показано проведення стегно-дистальної реконструкції. Зниження рівня ПСШ та IP на ГАС і ТПС відбувається за рахунок блокування оклюзивним процесом стегно-підколінного сегмента анастомозів ГАС із низхідною артерією коліна, підколінною артерією та гомілковими артеріями і створюються умови для розвитку тромбозу. Тобто первинний об'єм оперативного втручання повинний був включати аортоклубово-біфеморальне алошунтування із фрормуванням стегно-дистального аутовенозного шунта на проблемній нижній кінцівці.

У 6 пацієнтів діагностовано тромбоз клубовостегнового сегмента (К-СС) контрлатеральної нижньої кінцівки. Термін до розвитку пізнього тромбозу К-СС контрлатеральної нижньої кінцівки після реваскуляризації проблемної нижньої кінцівки знаходився в межах 24-31 місяць. Пацієнти були госпіталізовані в період від 32 до 72 год з моменту появи симптомів гострої артеріальної непрохідності. Оперативне лікування проводили в перші 24-36 год з моменту госпіталізації. Пацієнтам було проведено клубово-стегнове алошунтування контрлатеральної нижньої кінцівки. В одному спостереженні операція була доповнена стегно-дистальним аутовенозним шунтуванням.

Причиною розвитку тромбозу контрлатерального клубово-стегнового сегмента $€$ те, що при первинній однобічній реконструкції клубово-стегнової зони не враховано стенотичний процес контрлатерального клубово-стегнового сегмента. На час первинного хірургічного втручання стенотичний процес контрлатеральної К-СС знаходився на рівні 4356 \%. Період від оперативного лікування проблемної нижньої кінцівки до появи симптоматики тромбозу контрлатеральної нижньої кінцівки (в середньому 21 місяць) був достатній для розвитку ще більш вираженого стенотичного процесу, що і спровокувало орормування тромба артеріального русла клубовостегнової зони контрлатеральної нижньої кінцівки.

3 метою попередження розвитку тромбозу артеріального русла клубово-стегнової зони контрлатеральної нижньої кінцівки після реваскуляризації клубово-стегнового артеріального басейну необхідно визначати рівень стенотичного процесу К-СС контрлатеральної нижньої кінцівки. Потрібно вказати, що стенотичний процес клубово-стегнової артеріальної зони в межах 65-75 \% сприяє підвищенню перифрерійного судинного опору і фрормує високу пікову систолічну швидкість по загальній клубовій артерії - (180-205) см/с. Останнє сприяє перерозподілу потоку крові в артеріальне русло протилежної нижньої кінцівки. Потік крові прямує у артеріальне русло із нижчим судинним опором - в артеріальний басейн реваскуляризованого клубово-стегнового сегмента. Високий периферійний судинний опір, зниження об'єму кровотоку по артеріальному руслу контрлатеральної нижньої кінціки - основні фрактори, що сприяють розвитку тромбозу клубово-стегнового артеріального русла контрлатеральної нижньої кінцівки. Наведені обставини вказують на те, що при однобічній атеросклеротичній оклюзії клубово-стегнового артеріального русла і виявленому стенотичному атеросклеротичному процесі (50 \% і вище) контрлатерального клубового артеріального сегмента показано проведення аорто-біфеморального алошунтування (патент на корисну модель № 115 930; № 133 589).

Прогресування атеросклеротичного процесу в пацієнтів після реваскуляризації аорто-клубово-стегно-підколінної артеріальної зони - основна причина фрормування ускладнень пізнього післяопераційного періоду. До найбільш частих ускладнень віддаленого післяопераційного періоду відносять тромбози сегмента реконструкції, алопротеза, аутовенозного шунта [3]. Для лікування тромбозу пізнього післяопераційного періоду запропоновано ряд реваскуляризуючих оперативних втручань [9-11]. У роботі представлено деякі причини розвитку тромбозу пізнього періоду після реваскуляризуючих операцій, які пов'язані з прогресуванням атеросклеротичного процесу, але мають залежність від локалізації ураження артеріального русла і вибору при цьому об'єму реконструктивної операції. До них віднесено 4 спостереження із пізнім тромбозом бранші аорто-клубово-біфеморального алопротеза й одноіменної ГАС та 6 спостережень із тромбозом клубово-стегнового сегмента контрлатеральної нижньої кінцівки. При урахуванні рівня стенотичного процесу клубово-стегнового сегмента контрлатеральної нижньої кінцівки в одному випадку та визначенні показника пікової систолічної швидкості (ПСШ) й індексу резистентності (IP) на рівні ГАС та тібіоперинеального стовбура (ТПС) в іншому при плануванні об'єму реваскуляризую-
ISSN 2706-6282(print)

ISSN 2706-6290(online)
Вісник медичних і біологічних досліджень

Bulletin of Medical and Biological Research
$3(5), 2020$ 
чої операції можна б було попередити розвиток пізнього тромбозу.

\section{ВИСНОВКИ}

При урахуванні рівня стенотичного процесу клубово-стегнового сегмента контрлатеральної нижньої кінцівки, визначенні показника пікової

\section{СПИСОК ЛІТЕРАТУРИ}

1. Тактика лечения мультифокального атеросклероза / П. И. Никульников, А. В. Ратушнюк, С. Н. Фуркало, А. А. Гуч // Вісник Української медичної стоматологічної академії. - 2012. - Т. 9, вип. 1. - С. 318-321.

2. Hallett J. V. Selection and preparation of highrisk patients for repair of abdominal aortic aneurysm / J. V. Hallett, T. C. Bower, K. J. Cherry // Mayo Clin. - 2004. - Vol. 69, No. 8. - P. 763-768.

3. Черняк В. А. Хірургічне лікування критичної ішемії нижніх кінцівок / В. А. Черняк // Серце і судини. - 2013. №1. - C. 54-63.

4. Белов Ю. В. Степаненко А.Б. Повторные реконструктивные операции на аорте и магистральных артериях / Ю. В. Белов, А. Б. Степаненко. - М. : Медицинское инорормационное агентство, 2009. - 176 с.

5. Профундопластика при хронічній ішемії нижніх кінцівок / В. І. Русин, В. В. Корсак, В. В. Русин [та ін.]. - Ужгород : Всеукраїнське державне видавництво «Карпати», 2018. - 180 c.

6. Губка В. А. Повторные реконструкции у больных облитерирующим атеросклерозом с отдаленными

\section{REFERENCES}

1. Nykulnykov P, Ratushnyuk A, Furkalo S, Guch A. [Tactics of treatment of multifocal atherosclerosis]. Visnyk Ukrainskoi medychnoi stomatolohichnoi akademii. 2012;9(1): 318-21. Ukrainian.

2. Hallett J, Bower T, Cherry K. Selection and preparation of high-risk patients for repair of abdominal aortic aneurysm. Mayo Clin. 2004;69(8): 763-8.

3. Chernyak V. [Surgical treatment of critical ischemia of the lower extremities]. Sertse i sudyny. 2013;1: 54-63. Ukrainian.

4. Belov Yu, Stepanenko A. Repeated reconstructive operations on the aorta and main arteries. [Повторные реконструктивные операции на аорте и магистральных артеріях] Moscow: Medytsynskoe informatsyonnoe agentstvo; 2009. Russian.

5. Rusyn V, Korsak V, Rusyn V, Gorlenko F, Kopolovecz I, Mashura V, Langazo O. Profundoplasty for chronic ischemia of the lower extremities. [Профрундопластика при хронічній ішемії нижніх кінцівок] Uzhhorod: Karpaty; 2018. Ukrainian.

6. Gubka V. [Repeated reconstructions in patients with систолічної швидкості й індексу резистентності на рівні ГАС та тібіоперинеального стовбура за умови включення наведених артеріальних сегментів в об'єм реваскуляризуючого втручання на магістральних артеріях, можна попередити розвиток пізнього тромбозу наведених сегментів.

осложнениями / А. В. Губка // Патология. - 2012. - № 2 (25). - C. 43-45.

7. The 30 Congress of the Europeans Society of Surgeons ( Copenhagen, Denmark, September 28-30, 2016) / E. L. Kalmykov, D. A. Skrypnik, R. A. Vinogradov, A. D. Gaibov // Angiologiia i Sosud khirurgiia. - 2017. - (1). - P. 143-147.

8. Recommended standards for reports dealing with lower extremity ischemia: Revised version / R. B. Rutherford, J. D. Baker, C. Ernst [et al.] // J. Vasc. Surg. - 1997. Vol. 25. - P. 517-538.

9. Кобза І. І. Реваскуляризація критично ішемізованих кінцівок у хворих з мультифокальними ураженнями артерій / І. І. Кобза. - Львів : НВП «Мета», 1997. - 247 с.

10. Cardia G. Reoperation on the femoral arterial bifurcation: technical notes and surgical strategy / G. Cardia, V. Cianci, D. Merlicco // Chir. Ital. - 2002. Vol. 54, No. 4. - P. 487-493.

11. Ковальчук Л. Я. Хірургія поєднаних і множинних атеросклеротичних оклюзій екстракраніальних артерій та аорто-стегнового сегмента / Л. Я. Ковальчук, І. К. Венгер, С. Я. Костів. - ТДМУ : Укрмедкнига, 2005. - С. 198.

obliterating atherosclerosis with long-term complications]. Patologiya. 2012;2(25): 43-5. Russian.

7. Kalmykov E, Skrypnik D, Vinogradov R, Gaibov A. The 30 Congress of the Europeans Society of Surgeons. Angiologiia i Sosud khirurgiya. 2017;1: 143-7.

8. Rutherford R, Baker J, Ernst C. Recommended standards for reports dealing with lower extremity ischemia. Journal Vascular Surgery. 1997;25: 517-38.

9. Kobza II. Revascularization of critically ischemic limbs in patients with multifocal arterial lesions. [Реваскуляризація критично ішемізованих кінцівок у хворих з мультифокальними ураженнями артерій] Lviv: Meta; 1997. Ukrainian.

10. Cardia G, Cianci V, Merlicco D. Reoperation on the femoral arterial bifurcation: technical notes and surgical strategy. Chir Ital. 2002;54(4): 487-93.

11. Kovalchuk L, Venger I, Kostiv S. Surgery of combined and multiple atherosclerotic occlusions of extracranial arteries and aorto-femoral segment. [Реваскуляризація критично ішемізованих кінцівок у хворих 3 мультисоокальними ураженнями артерій] Ternopil: Ukrmedknyha; 2005. Ukrainian. 